\title{
Wound myiasis in Western Europe: prevalence and risk factors in a changing climate scenario
}

\author{
Erika Andreatta $\cdot$ Luigi Bonavina $\mathbb{D}$
}

Received: 22 May 2021 / Accepted: 25 May 2021 / Published online: 29 June 2021

(C) The Author(s) 2021

\begin{abstract}
Summary
Background Myiasis is an infestation of neglected open wounds by fly larvae. Global warming, related climate changes, and increased traveling in tropical countries may contribute to the worldwide diffusion of new fly species. Common risk factors for myiasis are advanced age, poor hygiene, malnourishment, social isolation, diabetes, cancer, and peripheral artery disease. The aim of this study was to review the characteristics of cases of myiasis reported in Europe. Methods A narrative review of cutaneous myiasis was performed using PubMed, EMBASE, Web of Science database, and the search terms "human," "myiasis," "cutaneous myiasis," "maggot," "Europe," "wound," with the combination of "AND" and "OR." In addition, hospital charts were reviewed to add personal experience to the literature review.

Results Overall, 52 articles, both single case reports and case series reporting cutaneous myiasis, were found in the medical literature of the past two decades. A total of 64 patients living in Europe were identified, of whom $36 \%$ had wound myiasis. In addition to the literature review, we report the case of a male patient who presented with myiasis within a deep scalp ulcer occurring after radiotherapy for basal cell carcinoma.

Conclusion Myasis is rare and possibly under-reported in Europe. The epidemiology of this infestation may be changing in the future due to climate variability, a rise in travel to tropical areas, and the migration of fly species.
\end{abstract}

\footnotetext{
E. Andreatta $\cdot$ Prof. L. Bonavina $(\bowtie)$

Department of Biomedical Sciences for Health, Division of General and Foregut Surgery, Policlinico San Donato, IRCCS, University of Milan, 20097 Milan, Italy

luigi.bonavina@unimi.it
}

Keywords Cutaneous fly infestation - Maggot infestation · Skin cancer · Global warming

\section{Main novel aspects}

- Over the past two decades, cutaneous myiasis in Western Europe has mostly been imported by returning travelers.

- The incidence of myiasis in Europe could rise in the future due to the effects of climate change and to the migration of fly species from tropical and subtropical countries.

- Wound myiasis may worsen the symptom burden and cause distress both to patients and caregivers.

- Appropriate wound care is essential to prevent the occurrence of myiasis.

\section{Introduction}

Climate change is widely regarded as one of greatest challenges facing ecological systems and biosecurity in the coming century. The planet is warming from the north to the south pole, and the global average temperature has increased by approximately $1{ }^{\circ} \mathrm{C}$ over the past century. Climate changes have led some animal species including mosquitos, ticks, and flies to thrive and, as a consequence, to spread diseases such as malaria and Zika virus infection. Contrary to other insect species, flies are predicted to increase in this warming scenario (Warming Climate Implies More Flies—and Disease, Feb. 20, 2019, www. scientificamerican.com).

Myasis (from the Greek, myia, meaning fly), first described by Hope in 1840, refers to a condition where fly larvae (maggots) infest the skin of a living human or vertebrate animals, feeding on dead or living tissues [1]. Myiasis shows seasonal variations, and the prevalence of this infestation is related to the latitude and 
Table 1 Cutaneous myiasis: summary of case reports in Western Europe (2000-2020)

\begin{tabular}{|c|c|c|c|c|c|c|c|c|c|}
\hline Author & Year & Country & No. pts & Sex & Age & Location & Type of lesion & Fly species & Comorbidities/Risk factors \\
\hline Delhaes [8] & 2001 & France & 1 & M & 21 & Leg & Wound & Calliphora vicina & I \\
\hline Logar [9] & 2001 & Slovenia & 1 & M & 25 & Leg & Furuncular & Dermatobia hominis & Trip to Peru \\
\hline Seppänen [10] & 2001 & Finland & 1 & M & 41 & Arm & Wound & $\begin{array}{l}\text { Cochliomyia hominivo- } \\
\text { rax }\end{array}$ & Trip to Brazil \\
\hline Guruttxaga [11] & 2001 & Spain & 1 & $\mathrm{~F}$ & 34 & Leg & Furuncular & $\begin{array}{l}\text { Cordylobia anthro- } \\
\text { pophaga }\end{array}$ & Trip to Senegal \\
\hline Harbin [12] & 2002 & UK & 1 & $\mathrm{~F}$ & 39 & Head & Furuncular & Dermatobia hominis & Trip to Belize \\
\hline $\begin{array}{l}\text { Hohenstein } \\
\text { [13] }\end{array}$ & 2004 & $\begin{array}{l}\text { Switzer- } \\
\text { land }\end{array}$ & 1 & M & 30 & Chest & Furuncular & Dermatobia hominis & Trip to Costa Rica \\
\hline Maier [14] & 2004 & Austria & 1 & M & 59 & Scapular area & Furuncular & Dermatobia hominis & Trip to Mexico \\
\hline Rubio [15] & 2005 & Spain & 3 & $\begin{array}{l}1 \mathrm{M} / \\
2 \mathrm{~F}\end{array}$ & 81 & Head and neck & Wound & $\begin{array}{l}\text { Chrysomya sp., Sar- } \\
\text { cophaga spp. }\end{array}$ & Head and neck tumor, radiotherapy \\
\hline Fusco [16] & 2005 & Italy & 1 & M & 50 & Foot & Furuncular & $\begin{array}{l}\text { Cordylobia anthro- } \\
\text { pophaga }\end{array}$ & Trip to Senegal \\
\hline Curtis [17] & 2006 & UK & 1 & $\mathrm{~F}$ & 61 & Leg & Furuncular & $\begin{array}{l}\text { Cordylobia anthro- } \\
\text { pophaga }\end{array}$ & Trip to Portugal \\
\hline Franza [18] & 2006 & Italy & 1 & M & 57 & Neck & $\begin{array}{l}\text { Tracheostomy } \\
\text { site }\end{array}$ & Lucilia Caesar & Overweight, pontomesencephalic hemorrhage \\
\hline Logar [19] & 2006 & Slovenia & 2 & $\begin{array}{l}1 \mathrm{M} / \\
1 \mathrm{~F}\end{array}$ & 47 & Shoulder & Furuncular & $\begin{array}{l}\text { Cordylobia anthro- } \\
\text { pophaga }\end{array}$ & Trip to Ghana \\
\hline Diaz Ley [20] & 2006 & Spain & 1 & $\mathrm{~F}$ & 53 & Gluteus & Furuncular & $\begin{array}{l}\text { Cordylobia anthro- } \\
\text { pophaga }\end{array}$ & Trip to Africa \\
\hline Calderaro [21] & 2007 & Italy & 1 & M & 28 & Head & Wound & Dermatobia hominis & Trip to Brazil \\
\hline Bongiorno [22] & 2007 & Italy & 1 & M & 45 & Head & Furuncular & Dermatobia hominis & Trip to Peru \\
\hline Goksu [23] & 2007 & Germany & 1 & M & 49 & Back & Furuncular & $\begin{array}{l}\text { Cordylobia anthro- } \\
\text { pophaga }\end{array}$ & Trip to Gambia \\
\hline Hakeem [24] & 2008 & UK & 1 & M & 54 & Back & Furuncular & $\begin{array}{l}\text { Cordylobia anthro- } \\
\text { pophaga }\end{array}$ & Work in West Africa, coronary heart disease \\
\hline Pica [25] & 2008 & Italy & 1 & $\mathrm{~F}$ & 61 & Back & Furuncular & Cordylobia spp. & Trip to Africa \\
\hline Veraldi [26] & 2009 & Italy & 1 & $\mathrm{~F}$ & 34 & Back & Furuncular & Dermatobia hominis & Trip to Jamaica \\
\hline Dutto [27] & 2009 & Italy & 1 & $F$ & 78 & Foot & Wound & Lucilia sericata & Chronic venous insufficiency \\
\hline $\begin{array}{l}\text { Sesterhenn } \\
{[28]}\end{array}$ & 2009 & Germany & 1 & M & 61 & Neck & Wound & Lucilia spp. & Squamous cell oropharyngeal carcinoma \\
\hline Kronert [29] & 2009 & Germany & 1 & $\mathrm{~F}$ & 61 & Back & Furuncular & Dermatobia hominis & Trip to Central America \\
\hline Dutto [30] & 2009 & Italy & 1 & $\mathrm{~F}$ & 79 & Foot & Wound & Sarcophaga cruentata & Diabetes mellitus \\
\hline Whitehorn [31] & 2009 & UK & 1 & M & 40 & Arm & Furuncular & $\begin{array}{l}\text { Cordylobia anthro- } \\
\text { pophaga }\end{array}$ & Trip to Uganda \\
\hline Schreiber [32] & 2010 & Germany & 1 & M & 31 & Arm & Furuncular & Dermatobia hominis & Trip to French Guiana \\
\hline Puente [33] & 2010 & Spain & 1 & M & 34 & Leg & Furuncular & Hypoderma lineatum & Trip to India \\
\hline Dutto [34] & 2011 & Italy & 1 & $\mathrm{~F}$ & 75 & Hand & Wound & Cyclorrhapha spp. & Cerebral hemorrhage \\
\hline Cecchini [35] & 2012 & France & 1 & M & 47 & Foot & Wound & Lucilia sericata & Diabetes mellitus \\
\hline Salvetti [36] & 2012 & Italy & 1 & M & 30 & Head & Wound & Calliphora vicina & $\begin{array}{l}\text { Cocaine and alcohol abuse, suicide attempt, } \\
\text { acute renal failure, rhabdomyolysis }\end{array}$ \\
\hline Nagy [37] & 2012 & Slovakia & 2 & M & 54 & Urogenital & Wound & Lucilia sericata & $\begin{array}{l}\text { Transitional cell carcinoma, alcohol abuse, } \\
\text { urogenital gangrene }\end{array}$ \\
\hline Dutto [38] & 2013 & Italy & 1 & M & 81 & Foot & Wound & Sarcophaga africa & Diabetes mellitus, peripheral arterial disease \\
\hline Osborne [39] & 2013 & UK & 1 & M & 36 & Head & Wound & Dermatobia hominis & Trip to Belize \\
\hline Kleine [40] & 2014 & Germany & 1 & M & 55 & Head & Wound & Chrysomya bezziana & Trip to Malaysia \\
\hline Lowe [41] & 2013 & UK & 1 & M & 38 & Head & Wound & $\begin{array}{l}\text { Cordylobia anthro- } \\
\text { pophaga }\end{array}$ & Trip to Africa \\
\hline Kay [42] & 2014 & UK & 1 & $\mathrm{~F}$ & 47 & Foot & Wound & Dermatobia hominis & Trip to Panama \\
\hline Rappelli [43] & 2014 & Italy & 1 & M & 63 & Back & Furuncular & Hypoderma spp. & Farmer \\
\hline Wollina [44] & 2015 & Germany & 3 & M & 82 & Head & Wound & Lucilia spp. & Squamous cell carcinoma \\
\hline Hirsch [45] & 2015 & France & 1 & M & 47 & Shoulder & Furuncular & Dermatobia hominis & Trip to Guyana \\
\hline Pezzi [46] & 2015 & Italy & 1 & M & 45 & Head & Furuncular & Cordylobia rhodaini & Trip to Uganda \\
\hline Gaci [47] & 2015 & France & 1 & M & 60 & Scrotum & Furuncular & Dermatobia hominis & Trip to South America \\
\hline
\end{tabular}


Table 1 (Continued)

\begin{tabular}{|c|c|c|c|c|c|c|c|c|c|}
\hline Author & Year & Country & No. pts & Sex & Age & Location & Type of lesion & Fly species & Comorbidities/Risk factors \\
\hline Landehag [48] & $\begin{array}{l}2011- \\
2016\end{array}$ & Norway & 7 & $\begin{array}{l}3 \mathrm{~F} / \\
4 \mathrm{M}\end{array}$ & 46 & Head & Furuncular & Hypoderma tarandi & I \\
\hline Villaescusa [49] & 2016 & Spain & 1 & M & 62 & Foot & Wound & Wohlfahrtia magnifica & $\begin{array}{l}\text { Diabetes mellitus, poor personal hygiene, } \\
\text { coronary artery disease }\end{array}$ \\
\hline $\begin{array}{l}\text { Giangaspero } \\
\text { [50] }\end{array}$ & 2017 & Italy & 1 & $\mathrm{~F}$ & 101 & Skin & Wound & $\begin{array}{l}\text { Sarcophaga argyros- } \\
\text { toma }\end{array}$ & Bedridden \\
\hline Hong How [51] & 2018 & UK & 1 & $\mathrm{~F}$ & 32 & Leg & Furuncular & $\begin{array}{l}\text { Cordylobia anthro- } \\
\text { pophaga }\end{array}$ & Trip to Gambia \\
\hline Wade [52] & 2018 & UK & 1 & $\mathrm{~F}$ & 55 & Head & Furuncular & Cordylobia rodhaini & Trip to Uganda \\
\hline Bernhardt [53] & 2018 & Germany & 1 & M & I & Foot & Wound & $\begin{array}{l}\text { Phormia regina, } \\
\text { Lucilia sericata }\end{array}$ & $\begin{array}{l}\text { Homeless, paranoid schizophrenia, drug and } \\
\text { alcohol abuse }\end{array}$ \\
\hline Demaj [54] & 2019 & Albania & 1 & M & 48 & Head & Wound & Lucilia sericata & Basal cell carcinoma \\
\hline Watkins [55] & 2019 & UK & 1 & $\mathrm{~F}$ & 50 & Head & Wound & Dermatobia hominis & Trip to Argentina \\
\hline Toberer [56] & 2019 & Germany & 1 & $\mathrm{~F}$ & 35 & Leg & Furuncular & Dermatobia hominis & Trip to Peru \\
\hline Dunphy [57] & 2019 & UK & 1 & M & 18 & Head & Furuncular & Dermatobia hominis & Trip to Belize \\
\hline Di Tullio [58] & 2019 & Italy & 1 & M & 52 & Head & Furuncular & Dermatobia hominis & Trip to Argentina \\
\hline $\begin{array}{l}\text { De Pasquale } \\
\text { [59] }\end{array}$ & 2019 & Italy & 1 & M & 34 & Head & Wound & Sarcophaga sp. & Poor sanitary conditions, psoriasis, lymphoma \\
\hline Oliva [60] & 2020 & Italy & 1 & $\mathrm{~F}$ & 22 & Gluteus & Furuncular & $\begin{array}{l}\text { Cordylobia anthro- } \\
\text { pophaga }\end{array}$ & Trip to Kenia \\
\hline
\end{tabular}

the life cycle of the fly species. According to the relationship between the host and parasite, there are three forms of myiasis: obligate (tropical in origin), facultative [2], and accidental [3]. The last two, although rare, can be found worldwide. Climate change and the migration of fly species due to increased travel to tropical areas may increase the incidence of this infestation in Western countries. Cutaneous myiasis is the most frequently encountered clinical form. Risk factors predisposing to this condition are open wounds, advanced age, poor hygiene, low socioeconomic conditions, psychiatric illness, alcoholism, metabolic disorders, vascular disease, cancer, and physical handicaps [4-7].

\section{Materials and methods}

We performed a search for articles reporting on cutaneous myiasis in adult patients, acquired in Western Europe or acquired overseas but diagnosed in Western Europe over the past two decades. A literature review was performed to identify all published articles on cutaneous myiasis in PubMed, EMBASE, and Web of Science database, using the keywords "human," "myiasis," "cutaneous myiasis," "Europe," "Western Europe," "wound," with "AND” and "OR." We also consulted the hospital electronic database to find the records of patients admitted to the emergency room for cutaneous parasitic infestations. Demographic and clinical patient data were extracted from the hospital charts. Written informed consent was obtained from patients.

\section{Results}

\section{Human cutaneous myiasis in Western Europe}

Our literature search yielded 1920 articles published between 2000 and 2020. Reports describing patients observed in countries other than Western Europe (Turkey, India, Pakistan, Malaysia, United States, Canada, Brazil, China, etc.) were excluded. A total of 52 papers were selected including 64 patients reported in Europe. The main patient characteristics are presented in Table 1 [8-60]. Myiasis was mainly described as furuncular (64\%) or associated with a wound (36\%). Reports comprised single case reports and case series including up to seven patients. The median age was 47 years (range 21-101), and $39(61 \%)$ patients were males; in more than $50 \%$ of patients, myiasis was acquired in a tropical country but diagnosed in Western/Southern Europe, mostly Italy and Spain. The principal anatomical site was the head and neck region (38\%), followed by lower limbs and trunk. Diabetes mellitus and head and neck tumors were the most common comorbidities. The main fly species involved where Dermatobia spp., Cordylobia spp., and Lucilia spp.

\section{Case report}

A 91-year-old man presented to the emergency department complaining of moderate bleeding from a skin lesion in the frontotemporal area. His medical history was notable for diabetes mellitus and invasive basal cell carcinoma treated first with surgery and then with radiotherapy (20 Gy) due to local recurrence. Physical examination revealed a deep, ulcerated lesion, $4 \times 5 \mathrm{~cm}$ in size, with numerous maggots inside. 

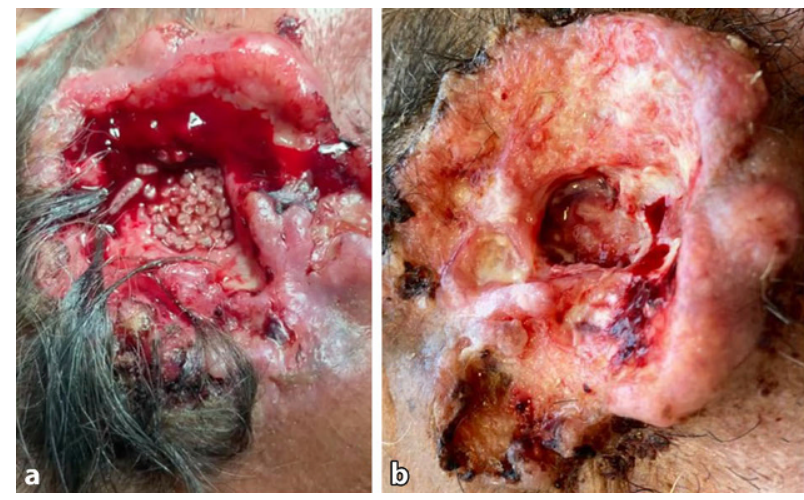

Fig. 1 a Maggots inside an ulcerated wound in the frontoparietal area; $\mathbf{b} 1$ week after mechanical removal of fly larvae and debridement; $\mathbf{c}, \mathbf{d}$ computed tomography showing bone

Mechanical removal of all larvae, intensive irrigation with saline solution, and wound debridement were performed. Laboratory findings were normal. A computed tomography scan showed full-thickness bony destruction and no meningeal lesions (Fig. 1). After multidisciplinary team discussion (surgeon, neurologist, radiologist), only frequent dressing changes and antibiotic therapy were recommended. One week later, the patient was doing well with no evidence of maggots and no signs of wound infection or neurologic involvement.

\section{Discussion}

This review shows that wound myiasis is rarely reported and possibly underestimated in Western Europe, confirming that epidemiological data on human myiasis are scant [7]. In our case, myiasis complicated the clinical course of an elderly patient with recurrent basalioma of the scalp after failed surgical excision and radiotherapy. Half of the patients in our review had a history of recent travel, the majority from Central-South America. Compared with the United States [61], reports of autochthonous cases of myiasis in Western Europe appear less common. In the future, climate change and possible migration of new fly species from tropical and subtropical countries could increase the incidence of this condition and modify the epidemiologic characteristics of human myiasis in Europe. In view of this changing scenario, larval identification by an entomologist and registration of all observed cases should be pursued [7]. Well-known risk factors predisposing to myiasis are open wounds, frailty syndrome, poor hygiene, low socioeconomic conditions, psychiatric illness, alcoholism, diabetes, vascular disease, and cancer. Complex wounds are frequently seen in nosocomial, hospice, and palliative medicine settings, and wound myiasis may worsen the symptom burden and may cause distress both to patients and caregivers [62]. Health education and prevention of conditions that favor myiasis infestation represent the most effective intervention. For in-

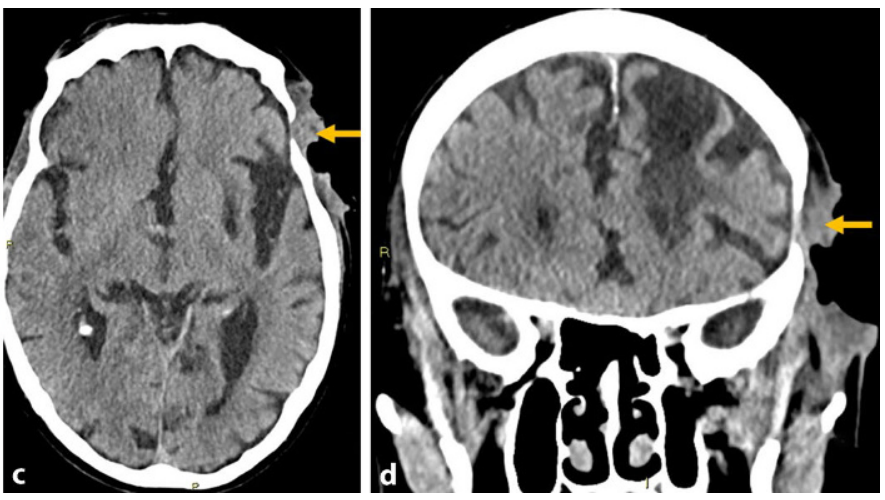

destruction (arrows) after radiotherapy for recurrent basal cell carcinoma of the skin

dividuals traveling to rural endemic areas, covering the body with long-sleeve shirts, pants, and hats, use of insect repellents, and sleeping on raised beds, in screened rooms, or under a net are recommended. Clothes should be hot-ironed and dried to remove residual eggs. Simple antisepsis and dressing are adequate to prevent wound myiasis [7].

In general, myiasis is a self-limited infestation and carries minimal morbidity. Treatment of cutaneouswound myiasis consists of application of toxic agents to kill the larvae or perilesional infiltration of local anesthetics to force the emergence of the larvae. Pharmacological treatment with ivermectin or tiabendazole has been proposed on the basis of anecdotal reports, mainly from veterinary medicine, but no controlled studies are available [7]. Mechanical debridement and frequent renewal of wound dressing are curative in the majority of cases $[62,63]$.

Interestingly, therapeutic myiasis involving sterile harvesting of facultative fly larvae applied on chronic wounds is a well-known option for necrosis debridement, disinfection, and enhanced healing [64-66]. Lucilia sericata is considered the most suitable species for therapeutic application [7].

Funding Open access funding provided by Università degli Studi di Milano within the CRUI-CARE Agreement.

\section{Declarations}

Conflict of interest E. Andreatta and L. Bonavina declare that they have no competing interests.

Ethical standards All procedures performed in studies involving human participants or on human tissue were in accordance with the ethical standards of the institutional and/or national research committee and with the 1975 Helsinki declaration and its later amendments or comparable ethical standards. Informed consent was obtained from the patient included in the study. Internal review board approval HSD 2020077.

Open Access This article is licensed under a Creative Commons Attribution 4.0 International License, which permits use, sharing, adaptation, distribution and reproduction in 
any medium or format, as long as you give appropriate credit to the original author(s) and the source, provide a link to the Creative Commons licence, and indicate if changes were made. The images or other third party material in this article are included in the article's Creative Commons licence, unless indicated otherwise in a credit line to the material. If material is not included in the article's Creative Commons licence and your intended use is not permitted by statutory regulation or exceeds the permitted use, you will need to obtain permission directly from the copyright holder. To view a copy of this licence, visit http://creativecommons.org/licenses/by/4.0/.

\section{References}

1. Robbins K, Khachemoune A. Cutaneous myiasis: a review of the common types of myiasis. Int J Dermatol. 2010;49:1092-8.

2. Burgess IF. Myiasis: maggot infestation. Nurs Times. 2003;99(13):51-3.

3. Ramana KV. Human myiasis. J Med Microbiol. 2012;1:2. https://doi.org/10.4172/2161-0703.1000e105.

4. Sesterhenn AM, Pfützner W, Braulke DM, et al. Cutaneous manifestation of myiasis in malignant wounds of the head and neck. Eur J Dermatol. 2009;19:64-8.

5. Ogbalu KO, Achufusi TG, Orlu E, et al. Human myiasis in neonates and children of the Niger delta wetlands and south-east Nigeria. JCDSA. 2011;1(4):171-6. https://doi. org/10.4236/jcdsa.2011.14026.

6. McGraw TA, Turiansky GW. Cutaneous myiasis. J Am Acad Dermatol. 2008;58:907-26.

7. Francesconi F, Lupi O. Myiasis. Clin Microbiol Rev. 2012;25:79-105.

8. Delhaes L, Bourei B, Scala L, et al. Case report: recovery of Calliphora vicinafirst-instarlarvaefromahuman traumatic wound associated with progressive necrotizing bacterial infection. Am J Trop Med Hyg. 2001;64:159-61.

9. Logar J, Beovic B, Triller C, et al. Subcutaneous myiasis caused by Dermatobia hominis. Scand J Infect Dis. 2001;33:153-5.

10. Seppänen M, Virolainen-Julkunen A, Kakko I, Vilkamaa P, Meri S. Myiasis during adventure sports race. Emerg Infect Dis. 2004;10(1):137-9. https://doi.org/10.3201/eid1001. 020825.

11. Gurrutxaga MA, Rementeria XB, Eguiluz GC, et al. Miasis cutanea por Cordylobia anthropophaga. Rev Esp Salud Publica. 2001;75:23-30.

12. Harbin LJ, Khan M, Thompson EM, et al. A sebaceous cyst with a difference: Dermatobia hominis. J Clin Pathol. 2002;55:798-9.

13. Hohenstein EJ, Buechner SA. Cutaneous myiasis due to Dermatobia hominis. Dermatology. 2004;208:268-70. https://doi.org/10.1159/000077317.

14. Maier H, Hönigsmann H. Furuncular myiasis caused by Dermatobia hominis, the human botfly. JAm Acad Dermatol. 2004;50:S26-S30.

15. Rubio C, Ladrón de Guevarab C, Martína MA, et al. Miasis cutáneas sobre lesiones tumorales: presentación de tres casos. Actas Dermosifiliogr. 2006;97(1):39-42.

16. Fusco FM, Nardiello S, Brancaccio G, et al. Cutaneous myiasis from Cordylobia anthropophaga in a traveller returning from Senegal. Infez Med. 2005;2:109-11.

17. Curtis SJ, Edwards C, Paul J. Case of the month: Cutaneous myiasis in a returning traveller from the Algarve: first report of Tumbu maggots, Cordylobia anthropophaga, acquired in Portugal. Emerg Med J.2006;23(3):236-7.
18. Franza R, Leo L, Minerva T, et al. Myiasis of the tracheostomy wound: case report. Acta Otorhinolaryngol Ital. $2006 ; 26: 222-4$.

19. Logar J, Šoba B, Parač Z. Cutaneous myiasis caused by Cordylobia anthropophaga. Wien Klin Wochenschr. 2006;118:180-2. https://doi.org/10.1007/s00508-0060535-z.

20. Díaz-Leya B, Pérez-Garcíab J, Baquedano-Sánchez F, et al. Nódulos cutáneos. Un souvenir vacacional. Enferm Infecc MicrobiolClin. 2006;24(10):659-60.

21. Calderaro A, Peruzzi S, Gorrini C, et al. Myiasis of the scalp due to Dermatobia hominis in a traveler returning from Brazil. Diagn Microbiol Infect Dis. 2008;60:417-8. https:// doi.org/10.1016/j.diagmicrobio.2007.10.021.

22. Bongiorno MR, Pistone G, Arico M. Myiasis with Dermatobia hominis in a Sicilian traveller returning from Peru. Travel Med Infect Dis. 2007;5:196-8.

23. Göksu T, Lonsdorf A, Jappe U, et al. Furunkuläre Hautläsionen nach Tropenaufenthalt. Internist. 2007;48:311-3. https://doi.org/10.1007/s00108-006-1760-2.

24. Hakeem MJML, Bhattacharyy DN. Exotic human myiasis. Travel Med Infect Dis. 2009;7:198-202. https://doi.org/10. 1016/j.tmaid.2009.05.007.

25. Pica R, Castellano C, Pignata D, et al. Human cutaneous myiasis: a case report. Clin Ter. 2008;159(6):431-3.

26. Veraldi S, Francia C, Persico MC, et al. Cutaneous Myiasis caused by Dermatobia hominis acquired in Jamaica. West Indian Med J. 2009;58(6):614.

27. Dutto M, Pomero F, Migliore E, et al. Cutaneous myiasis in a geriatric patient. Parassitologia. 2010;52:435-8.

28. Whitehorn JS, Whitehorn C, Thakrar NA, et al. The dangers of an adventurous partner: Cordylobia anthropophaga infestation in London. Trans R Soc Trop Med Hyg. 2010;104:374-5.

29. Sesternhenn AM, Pfützner W, Braulke DM, et al. Cutaneous manifestation of myiasis in malignant wounds of the head and neck. Eur J Dermatol. 2009;19(1):64-8.

30. Krönert C, Wollina U. Painful, slow developing abscesses. Furuncular myiasis due to double skin infestation by Dermatobia hominis. J Dermatol Case Rep. 2009;2:24-6. https://doi.org/10.3315/jdcr.2009.1028.

31. Dutto M, Poggi A. Cutaneous myiasis from Sarcophaga cruentata (Diptera: Sarcophagidae) in diabetic foot. G Ital Microbiol Med Odontoiatr Clin. 2009;XIII(2):46-8.

32. Schreiber HA, RenklAC, LapinskiW, etal. Myiasis after study trip to French Guiana. J Dtsch Dermatol Ges. 2010;8:357-9. https://doi.org/10.1111/j.1610-0387.2009.07257.x.

33. Puente S, Otranto D, Panadero R, et al. First diagnosis of an imported human myiasis caused by Hypoderma sinense (Diptera: Oestridae), detected in a European traveler returning from India. J Travel Med. 2010;17(6):419-23. https://doi.org/10.1111/j.1708-8305.2010.00464.x.

34. Dutto M, Bertero M. Cutaneous superficial myiasis: report of a rare nosocomial parasitic disease caused by Sarcophaga spp. (Diptera,Sarcophagidae). Cent Eur J Public Health. 2011;19(4):232-4.

35. Cecchini J, de Prost N, Mekontso-Dessap A, et al. Lifethreatening endobronchial myiasis. Intensive Care Med. 2012;38:1727-8. https://doi.org/10.1007/s00134-0122615-z.

36. Salvetti M, Corbellini C, Aggiusti C, et al. Calliphora vicina human myiasis: a case report. Intern Emerg Med. 2012;7(2):S135-S7. https://doi.org/10.1007/s11739-0110720-6.

37. Nagy V. Unusual presentation of the urogenital myiasis caused by Lucilia sericata (Diptera: Calliphoridae). Ann AgricEnviron Med. 2012;19(4):802-4. 
38. Dutto M, Pellegrino M, Vanin S. Nosocomial myiasis in a patient with diabetes. JHosp Infect. 2013;83:74-6.

39. Osborne M, O'Shearn MK. Sebaceous cysts with unpleasant twists: cutaneous myiasis with Dermatobia hominis. J R Nav Med Serv. 2013;99(2):50-2.

40. Kleine C, Schoefer H, Amendt J, et al. Cutaneous myiasis in a patient with seborrhoeic eczema. Lancet. 2014;383(9921):1012.

41. Lowe P, Naseem S, Bailey C. Cordylobia anthropophaga: a rare surgical emergency in the UK. BMJ Case Rep. 2013; https://doi.org/10.1136/bcr-2013-008659.

42. Kay S, Butt D, Lidder S, et al. A painful toe: botfly myiasis. BMJ Case Rep. 2013; https://doi.org/10.1136/bcr-2013201860.

43. Rappelli P, Varcasia A, Vargiu A, et al. Case report: First report of autochthonous human cutaneous myiasis caused by Hypoderma lineatum in Europe. Am J Trop Med Hyg. 2018;99(3):618-9. https://doi.org/10.4269/ajtmh.18-0100.

44. Wollina U. Myiasis on squamous cell carcinoma of skin. Wien Med Wochenschr. 2015;165:79-82. https://doi.org/ 10.1007/s10354-014-0326-5.

45. Hirsch G, Jeandel R, Biechler M, et al. Myiase furonculoïde à Dermatobia hominis: diagnostic fortuit sur la coupe macroscopique extemporanée d'un nodule cutané. Ann Dermatol Venereol. 2015;142:776-9. https://doi.org/10. 1016/j.annder.2015.10.586.

46. Pezzi M, Cultrera R, Chicca UM, et al. Furuncular myiasis caused by Cordylobia rodhaini (Diptera: Calliphoridae): a case report and a literature review. J Med Entomol. 2015;52(2):151-5. https://doi.org/10.1093/jme/tju027.

47. Gaci R, Delord M, Parola P, et al. Extended perineal Dermatobia hominis myiasis in a traveler returning from South America. JAMADermatol. 2015;151:12.

48. Landehag J, Skogen A, Åsbakk K, et al. Human myiasis caused by the reindeer warble fly, Hypoderma tarandi, case series from Norway, 2011 to 2016. Euro Surveill. 2017;22(29):30576. https://doi.org/10.2807/1560-7917. ES.2017.22.29.30576.

49. Villaescusa JM, Angulo I, Pontón A, et al. Infestation of a diabetic foot by Wohlfahrtia magnifica. J Vasc Surg Cases Innov Tech. 2016;2:119-22.

50. Giangaspero A, Marangi M, Balotta A, et al. Wound myiasis caused by Sarcophaga (Liopygia) Argyrostoma (RobineauDesvoidy) (diptera: Sarcophagidae): additional evidences of themorphologicalidentification dilemma andmolecular investigation. ScientificWorldJournal. 2017; https://doi. org/10.1155/2017/9064531.

51. Hong How E, Yap D, Mbakada N. An exotic abscess within the United Kingdom from the Gambia: a case report. J Med Case Reports. 2017;11:310. https://doi.org/10.1186/ s13256-017-1472-3.
52. Wade N, Shahi F, Mawer D, et al. Rare cutaneous myiasis of the face due to Lund's fly (Cordylobia rodhaini) in a British traveller returning from Uganda. BMJ Case Rep. 2019;12:e228070. https://doi.org/10.1136/bcr-2018228070.

53. Bernhardt V, Finkelmeier F, Tal A, et al. Multispecies blow fly myiasis combined with hypothermia in a man assumed to be dead. Parasitol Res. 2018;117:579-83. https://doi.org/ 10.1007/s00436-017-5691-8.

54. Demaj D, Jorgaqi E, Zikaj G, et al. Furuncular myiasis of the scalp associated with pigmented basal cell carcinoma: first case diagnosed in Albania. Dermatol Ther. 2020;33:e13198. https://doi.org/10.1111/dth.13198.

55. Watkins R, Kolar M, Ralston D. Getting under your skin: botfly myiasis. BMJ Case Rep. 2019;12:e229666. https:// doi.org/10.1136/bcr-2019-229666.

56. Toberer F, Hanner S, Haus G, et al. Furuncular myiasis of the lowerleg. Acta Dermatovenerol Croat. 2019;27(3):190-1.

57. Dunphy L, Sood V. Dermatobia hominis 'the human botfly' presenting as a scalp lesion. BMJ Case Rep. 2019;12:e228310. https://doi.org/10.1136/bcr-2018228310.

58. Di Tullio F, MandelVD, Miglietta R, et al. Cutaneous myiasis in a traveller returning from Argentina. Dermatol Ther. 2019;32:e12996. https://doi.org/10.1111/dth.12996.

59. De Pasquale R, Pulvirenti J, Messina AMI, et al. Myiasis from Sarcophaga spp. in a patient with cutaneous lymphoma. Infez Med. 2019;3:340-4.

60. Oliva E, Bargiggia G, Quinzan G, et al. Furuncular myiasis in Italian traveler returning from Kenya. J Infect Dev Ctries. 2020;14(1):114-6. https://doi.org/10.3855/jidc.11560.

61. Sherman RA. Wound myiasis in urban and suburban United States. Arch Intern Med. 2000;160:2004-14.

62. Waidyaratne G, Zhou S, O'Neil T, Marks A. Management of wound myiasis in the hospice and palliative medicine setting. J Palliat Med. 2020;24(5):797-800.

63. Bernhardt V, Finkelmeier F, Verhoff MA, Amendt J. Myiasis in humans-a global case report evaluation and literature analysis. Parasitol Res. 2019;118:389-97.

64. Livingston SK, Prince LH. The treatment of chronic osteomyelitis with special reference to the use of maggot active principle. JAMA. 1932;98(14):1143-9.

65. Ziffren SE, Heist HE, May SC, Womack NA. The secretion of collagenase by maggot and its implication. Ann Surg. 1953;138(6):932-4.

66. Bonn D. Maggot therapy: an alternative for wound infection. Lancet. 2000;356:1174.

Publisher's Note Springer Nature remains neutral with regard to jurisdictional claims in published maps and institutional affiliations. 